\title{
Leonotis nepetifolia Protects against Acetaminophen-Induced Hepatotoxicity: Histological Studies and the Role of Antioxidant Enzymes
}

\section{Williams AF ${ }^{1 *}$, Clement $\mathbf{Y N}^{1}$, Nayak SB${ }^{2}$ and Rao AVC ${ }^{3}$}

${ }^{1}$ Pharmacology Unit, Basic Health Sciences, Faculty of Medical Sciences, University of the West Indies, St Augustine, Trinidad and Tobago ${ }^{2}$ Biochemistry Unit, Basic Health Sciences, Faculty of Medical Sciences, University of the West Indies, St Augustine, Trinidad and Tobago

${ }^{3}$ Pathology and Microbiology Unit, Basic Health Sciences, Faculty of Medical Sciences, University of the West Indies, St Augustine, Trinidad and Tobago

\begin{abstract}
Aim of the study: High dose acetaminophen (APAP) increases the risk of liver injury caused by oxidative stress due to accumulation of reactive species. Although $\mathrm{N}$-acetyl cysteine is the standard antidote used to treat acute APAPinduced liver failure, we proposed that known antioxidant phytochemicals in Leonotis nepetifolia extracts would protect against APAP-induced hepatic injury by modulating the activities of antioxidant enzymes.

Materials and methods: Methanol and aqueous extracts of $L$. nepetifolia were orally administered in doses ranging $(250 \mathrm{mg} / \mathrm{kg}$ to $1000 \mathrm{mg} / \mathrm{kg}$ ) as pre- and post-treatment with high dose APAP (550 mg/kg) to Swiss albino mice. Twenty-four hours after the final dose, animals were euthanized and blood and liver collected for liver enzymes (ALT and AST), histological assessment and antioxidant enzyme assays.

Results: Methanol and aqueous extracts as pre-treatment and post-treatment protected against hepatic injury. Extracts abrogated the 14-fold and 4-fold APAP-induced increases in ALT and AST respectively, including histopathological damage $(p<0.05)$. Extracts reversed APAP-induced 4-fold and 14-fold increases in GR and SOD activities respectively $(p<0.05)$. Additionally, extracts reversed APAP-induced decline in GPx activity; particularly the aqueous extract as pre-treatment increased GPx activity up to 2.2 -fold over saline-treated controls $(p<0.05)$.

Conclusions: Extracts, as pre-treatment and post-treatment, prevented APAP-induced hepatic injury by modulating the activities of antioxidant enzymes. Of particular interest, is the reversal of APAP-induced decrease in GPx activity and increase in SOD activity? Extract-induced increase in GPx activity would facilitate the scavenging of hydroperoxide and peroxide reactive species generated by high dose APAP. We propose that antioxidant phytochemicals in $L$. nepetifolia may be acting as free radical scavengers which results in reduced SOD activity.
\end{abstract}

\section{Keywords: L. nepetifolia; Reductase; Catalase}

Abbreviations: APAP: Acetaminophen; ALT: Alanine Amino transaminase; AST: Aspartate Aminotransferase; GR: Glutathione Reductase; GPx: Glutathione Peroxidase; SOD: Superoxide Dismutase; CAT: Catalase; NAPQI: N-acetyl-p-benzoquinoneimine; CYP2E1: Cytochrome 2E1.

\section{Introduction}

The liver is the major organ responsible for the metabolism of xenobiotics and it is susceptible to drug-induced injury, including drug overdose and deleterious drug-drug interactions. Acetaminophen (APAP) is widely used as an over-the-counter analgesic and antipyretic. It is the drug most commonly associated with drug-induced hepatic injury requiring hospitalization, making it a serious public health concern. Persons at risk for hepatic APAP injury include patients prescribed high daily doses (more than $4 \mathrm{~g}$ /day) on a long-term basis [1], as well as those who intentionally or accidentally overdose [2-4].

At therapeutic doses APAP is primarily detoxified by Phase 2 enzymes to inactive conjugates with minute amounts being metabolized by CYP2E1 to the short-lived, but highly reactive, NAPQI. NAPQI is efficiently detoxified by combining with reduced glutathione to form an inactive conjugate. However, at high doses Phase 2 conjugation pathways become saturated and more APAP is converted to NAPQI, depleting glutathione stores and causing accumulation of this highly reactive species. Although the precise mechanism of APAP-induced hepatotoxicity is not fully understood, it is proposed that NAPQIinduced oxidative stress culminates in cellular necrosis and lipid peroxidation [5].

Although $\mathrm{N}$-acetyl cysteine (NAC) is the standard antidote routinely used in the clinical setting for the management of APAP overdose, herbal remedies are becoming increasingly popular as "natural" remedies to treat a wide range of liver disorders [6-8]. Leonotis nepetifolis, commonly called Shandilay in Trinidad, is among the most commonly used herbs on the island [9]; it is an upright dicotyledonous plant, growing up to one meter in height, with square-shaped stems, soft serrated heart-shaped leaves and a globose cluster of flowers at the apex [10].

Several compounds such as diterpenes, glycosidic iridoids, stigmasterol, flavonoids and tannins have been isolated from the leaves of L. nepetifolia [11-13]. Additionally, actesoide, martinoside and lavandulipolioside have also been isolated in the stems and these compounds have been shown to possess potent antioxidant activity [14].

In this study we used high dose APAP to induce liver injury to investigate the hepatoprotective properties of methanol and aqueous extracts L. nepetifolia before (pre-treatment) and after (post- treatment) hepatic insult. We proposed that both extracts would prevent liver damage by abolishing the expected APAP-induced increase in liver enzymes, whilst maintaining liver morphology. We also proposed that L. nepetifolia extracts would modulate the activities of antioxidant enzymes (catalase (CAT), glutathione peroxidase (GPx), glutathione

*Corresponding author: Arlene Williams, Pharmacology Unit, Faculty of Medical Sciences, The University of the West Indies, St. Augustine, Trinidad and Tobago, Tel: +18686638613; E-mail: arlene.williams@sta.uwi.edu

Received April 29, 2016; Accepted May 12, 2016; Published May 18, 2016

Citation: Williams AF, Clement YN, Nayak SB, Rao AVC (2016) Leonotis nepetifolia Protects against Acetaminophen-Induced Hepatotoxicity: Histological Studies and the Role of Antioxidant Enzymes. Nat Prod Chem Res 4: 222. doi:10.4172/23296836.1000222

Copyright: (c 2016 Williams AF, et al. This is an open-access article distributed under the terms of the Creative Commons Attribution License, which permits unrestricted use, distribution, and reproduction in any medium, provided the original author and source are credited. 
Citation: Williams AF, Clement YN, Nayak SB, Rao AVC (2016) Leonotis nepetifolia Protects against Acetaminophen-Induced Hepatotoxicity: Histological Studies and the Role of Antioxidant Enzymes. Nat Prod Chem Res 4: 222. doi:10.4172/2329-6836.1000222

Page 2 of 7

reductase (GR) and superoxide dismutase (SOD)) in the presence of toxic APAP to facilitate hepatoprotection.

\section{Materials and Methods}

\section{Reagents and drug}

Methanol (JT Baker), HEPES buffer, EGTA, Sucrose, TrisHCL (Sigma-Aldrich), Trichloromethane (Reidel-deHaën), N-2Hydroxyethylpiperazine-N'-2-ethanesulfonic acid (HEPES), Ethylene glycol tetraacetic acid, $\mathrm{NaCl}$ (AnalaR), acetaminophen (SigmaAldrich).

\section{Preparation of plant extracts}

Fresh plant material was obtained from two sites in North Trinidad. The botanist at the National Herbarium, University of the West Indies, St Augustine assigned the voucher number TRIN 36510 to the specimen supplied. Collected plant material was thoroughly washed, oven-dried at $40^{\circ} \mathrm{C}$ to constant weight and mill-ground. For the methanol extract, milled plant material was exhaustively extracted with solvent, vacuum filtered and rotary evaporated to dryness at $45^{\circ} \mathrm{C}$. The gummy product was weighted $50 \mathrm{mg} / \mathrm{ml}$ stock for dosing regimen. The aqueous extract was prepared by infusing the milled plant material in normal saline at $80^{\circ} \mathrm{C}$ for one hour at a weigh of $50 \mathrm{mg} / \mathrm{ml}$. After cooling the mixture was vacuum filtered and the filtrate used.

\section{Animals}

Swiss Albino male mice (25-35 g) were obtained from the School of Veterinary Medicine Animal House at UWI. following institutional ethical approval. Animals were housed at constant room temperature $\left(25 \pm 2^{\circ} \mathrm{C}\right)$, maximum of 3 animals per cage, with free access to food and water and handled according to International Guidelines [15]. APAP and plant extract preparations were orally administered and 5-10 animals were used per treatment group.

\section{Determination of non-lethal APAP dose}

A stock APAP suspension $(30 \mathrm{mg} / \mathrm{ml})$ was prepared in warmed $0.9 \%$ saline solution. Increasing doses of APAP ( 200 to $600 \mathrm{mg} / \mathrm{kg})$ were orally administered and gross behaviour was observed and survival rates noted over a 24 -hour period. For surviving animals blood was collected by cardiac puncture (for ALT/AST assays) and liver harvested for histological assessment and antioxidant enzyme assay.

\section{Pre-treatment and post-treatment experimental study designs}

Pre-treatment animals received by oral gavage, either 250, 500, 750 or $1000 \mathrm{mg} / \mathrm{kg}$ plant extract (aqueous or methanol) daily over three days followed by toxic non-lethal dose of APAP administered two hours following the final plant extract dose. Post-treatment design [16], animals were administered 250, 500, 750 or $1000 \mathrm{mg} / \mathrm{kg}$ plant extract (aqueous or methanol) one (1) hour after dosing with $550 \mathrm{mg} /$ $\mathrm{kg}$ APAP. For both treatments, animals were euthanized at 24 hours after the last dose by cervical dislocation following which blood and liver were collected. Control animals received orally saline at the same time points.

\section{Assays for liver enzymes}

Blood was allowed to clot for about 30 minutes at ambient temperature, centrifuged at $10,000 \mathrm{rpm}$ for 3-5 minutes, serum collected and separated for ALT and AST assays using the Vitros V250 chemistry analyzer.

\section{Histological assessment of hepatotoxicity}

Livers were removed (the bile duct carefully dissected) and thoroughly washed in cold $0.9 \%$ saline. The left lateral lobe was fixed in $10 \%$ formol-saline solution, processed in paraffin following standardized technique for histological assessment using the haemotoxylin and eosin staining technique [17]. The grading scheme for hepatocellular damage was adapted from Ref. [18]: Grade $0=\mathrm{No}$ Lesions; Grade $1 / 2=$ individual necrotic cells at $1^{\text {st }}$ layer (Zone I); Grade $1=$ necrotic cells at $2^{\text {nd }}$ or $3^{\text {rd }}$ layers; Grade $2=$ necrotic cells extending 3 -cell layers (Zone II); Grade 3=necrotic cells extending from one central vein to the next (Zone III). The histopathological assessment was conducted by an independent anatomical pathologist blinded to treatment.

\section{Determination of antioxidant enzyme activities [19]}

Superoxide Dismutase (SOD) assay: Total superoxide dismutase activity was measured using a kit Cayman Chemicals (Michigan, USA). Briefly, tissue was homogenized in cold $16.8 \mathrm{mM}$ HEPES ( $\mathrm{pH}$ 7.2) containing 1mM EGTA, $210 \mathrm{mM}$ mannitol and $70 \mathrm{mM}$ sucrose. Twenty microliters of supernatant containing $40 \mu \mathrm{g}$ of protein was used in the assay. The reaction was initiated by adding xanthine oxidase, incubated at room temperature for 20 minutes and absorbance measured at $450 \mathrm{~nm}$.

Catalase (CAT) assay: Catalase activity was measured using a kit Cayman Chemicals (Michigan, USA). Briefly, tissue was homogenized in cold $50 \mathrm{mM}$ phosphate buffer (pH 7.0) containing 1mM EDTA. Twenty microliters of supernatant containing $40 \mu \mathrm{g}$ of protein was used in the assay. The reaction was initiated by adding hydrogen peroxide $\left(\mathrm{H}_{2} \mathrm{O}_{2}\right)$, which is converted by catalase into water and molecular oxygen, incubated for 20 minutes at room temperature and absorbance read at $540 \mathrm{~nm}$.

Glutathione Peroxidase (GPx) assay: Cellular glutathione peroxidase activity was measured using a kit supplied by Cayman Chemicals (Michigan, USA). Briefly, tissue was homogenized in cold $50 \mathrm{mM}$ Tris-HCL buffer ( $\mathrm{pH}$ 7.6) containing $5 \mathrm{mM}$ EDTA and $1 \mathrm{mM}$ DTT. Twenty microliters containing $40 \mu \mathrm{g}$ of protein was used in the assay. Glutathione peroxidase oxidizes NAPDH to NADP and the reaction is measured at $340 \mathrm{~nm}$.

Glutathione Reductase (GR) assay: Glutathione reductase activity was measured using a kit Cayman Chemicals (Michigan, USA). Briefly, tissue was homogenized in cold $50 \mathrm{mM}$ phosphate buffer ( $\mathrm{pH} 7.0$ ) containing $1 \mathrm{mM}$ EDTA. Twenty microliters containing $40 \mu \mathrm{g}$ of protein was used in the assay, and the reaction was initiated with $50 \mu \mathrm{l}$ GR NADPH and absorbance read at $340 \mathrm{~nm}$.

\section{Statistical analysis}

All data are expressed as mean \pm standard error, and were subjected to normality test. After determining normality, one-way ANOVA was used to determine statistical differences in ALT, AST, histological grade, CAT, SOD, GPx and GR activities between treatment groups. Kruskal- Wallis test was used for non-parametric data. Following these tests, Scheffé Test was performed. Significance was determined at $p<0.05$.

\section{Results}

\section{Determination of toxic non-lethal APAP dose}

Groups of mice $(n=6)$ were orally administered increasing doses of APAP ranging from 200 to $600 \mathrm{mg} / \mathrm{kg}$, and observed for 24 hours. 
Citation: Williams AF, Clement YN, Nayak SB, Rao AVC (2016) Leonotis nepetifolia Protects against Acetaminophen-Induced Hepatotoxicity: Histological Studies and the Role of Antioxidant Enzymes. Nat Prod Chem Res 4: 222. doi:10.4172/2329-6836.1000222

Page 3 of 7

At $600 \mathrm{mg} / \mathrm{kg}, 5$ out of 6 animals died, and the next lowest dose $(550$ $\mathrm{mg} / \mathrm{kg}$ ) was used as the toxic non-lethal dose. Compared with salinetreated controls, this dose caused a significant 14 -fold and 4 -fold increase in ALT and AST respectively (Table 1; Figures 1a and 1b). On histopathological examination this dose produced widespread centrilobular necrosis (characterized by karyorrhexis and karyolysis), with visibly enlarged hepatocytes extending to portal regions accompanied by loss of cellular arrangement and enlarged sinusoidal regions (Table 2 and Figure 2b). This dose of APAP induced a 14-fold and 4-fold increase in SOD and GR activities respectively, with no effect on CAT activity. However, GPx activity decreased to about $35 \%$ of saline-treated control levels, $p<0.01$ (Tables 3 and 4 ).

\section{Pre-treatment and post-treatment effects on serum liver enzymes}

Pre-treatment with all doses of methanol extract significantly reduced the 14-fold APAP-induced increase in $\operatorname{ALT}(\mathrm{F}(6,33)=18.48$, $\mathrm{p}<0.05$ ) (Table 1). Additionally, ALT levels in saline controls and animals pre-treated with the lower doses of methanol extracts were statistically similar, except at higher doses. Although the higher extract doses $750 \mathrm{mg} / \mathrm{kg}$ and $1000 \mathrm{mg} / \mathrm{kg}$ produced a 3 to 4 -fold increase in ALT, this was significantly lower than the increase seen with APAP alone. With regards to effect on AST levels, pre-treatment with all doses of the methanol extract abolished the significant APAP-induced increase $(\mathrm{F}(6,33)=8.44, p<0.05)$.

Similarly, the aqueous extract as pre-treatment abrogated the APAP-induced increase in both $\operatorname{ALT}(\mathrm{F}(6,29)=17.45, p<0.05)$ and AST $(\mathrm{F}(6,29)=10.35, p<0.05)$. As with the methanol extract, ALT levels between saline controls and animals pre-treated with the lower doses were similar. Although ALT levels at $1000 \mathrm{mg} / \mathrm{kg}$ dose were elevated it was significantly lower than that seen with APAP alone. The trend of increasing ALT with increasing doses of extracts as pretreatment suggests that the lower doses may be providing greater hepatoprotection.

All doses of the methanol extract as post-treatment abolished the APAP-induced increase in both $\operatorname{ALT}(\mathrm{F}(6,36)=39.75, p<0.01)$ and AST $(F(6,36)=16.57, p<0.01)$. Although animals given $750 \mathrm{mg} / \mathrm{kg}$ and $1000 \mathrm{mg} / \mathrm{kg}$ aqueous extract as post-treatment had a 2- to 3-fold increase in ALT levels compared with saline controls, $p<0.05$, these increases were significantly lower than the 14-fold APAP-induced increase, $p<0.05$. For the aqueous extract, post-treatment similarly abrogated the increases in both ALT $(\mathrm{F}(6,30)=16.63, p<0.05)$ and AST $(\mathrm{F}(6,30)=12.83, p<0.01)$.

\section{Pre-treatment and post-treatment effects of extracts on hepatic histopathology}

Pre-treatment with methanol extract at 250, 500 and $750 \mathrm{mg} /$ $\mathrm{kg}$ significantly reduced the APAP- induced hepatic damage (F (6, $33)=4.89, p<0.05)$, Table 2 and Figures $2 \mathrm{a}-2 \mathrm{c}$. However, at $1000 \mathrm{mg} / \mathrm{kg}$ hepatic injury was observed to a similar extent as APAP-alone treated animals, $p=0.12$ (Figure $2 \mathrm{~d}$ ). All pre-treatment doses of the aqueous extract abolished the APAP-induced hepatic damage (F $(6,29)=7.95$, $p<0.05)$; although there was marginal increase in hepatic damage seen with increasing extract doses (Figures $4 \mathrm{a}-4 \mathrm{~d}$ ).

At 500,750 and $1000 \mathrm{mg} / \mathrm{kg}$ the methanol extract prevented the APAP-induced pathological damage as post-treatment $(\mathrm{F}(6,36)=9.82$, $p<0.05$ ) (Figures 3b-3d). However, at $250 \mathrm{mg} / \mathrm{kg}$ the methanol extract (Figure 3a) did not prevent the significant APAP-induced hepatic damage, with significantly higher histological scores compared with saline controls, $p=0.02$. All doses of the aqueous extract, except $750 \mathrm{mg} /$ $\mathrm{kg}$, at post-treatment had no effect on preventing the APAP- induced liver damage $(F(6,33)=7.82, p<0.05$ with an effect size $(\eta 2)$ of $58.7 \%)$ (Figures 5a-5d).

\section{Pre-treatment and post-treatment effects of extracts on antioxidant enzymes}

Pre-treatment with $250 \mathrm{mg} / \mathrm{kg}$ and $500 \mathrm{mg} / \mathrm{kg}$ methanol extract had no significant effect on SOD activity compared with saline-treated controls; but at $750 \mathrm{mg} / \mathrm{kg}$ and $1000 \mathrm{mg} / \mathrm{kg}$ enzyme activity increased 2.4-fold and 4.0-fold respectively (Table 3 ). However, these levels were significantly lower than the 14 -fold increase in SOD activity induced by APAP $(\mathrm{F}(6,34)=165.70, p<0.05)$ (Table 3$)$. Similarly, pre-treatment with all doses of the aqueous extract abolished the APAP-induced increase in SOD activity $(\mathrm{F}(6,29)=243.21, p<0.05)$, despite a 2.3 fold increase in activity at $500 \mathrm{mg} / \mathrm{kg}$ (Table 4). Post-treatment with methanol extracts at $250 \mathrm{mg} / \mathrm{kg}, 500 \mathrm{mg} / \mathrm{kg}$ and $1000 \mathrm{mg} / \mathrm{kg}$ caused a significant $25 \%$ to $50 \%$ decrease in SOD activity compared with salinetreated controls, with a moderate 2.8 - fold at $750 \mathrm{mg} / \mathrm{kg}$ dose (Table 3 ). However, these changes were significantly lower than the 14 -fold APAP-induced increase $(\mathrm{F}(6,36)=319.30, p<0.05)$. Similarly, the 500 $\mathrm{mg} / \mathrm{kg}, 750 \mathrm{mg} / \mathrm{kg}$ and $1000 \mathrm{mg} / \mathrm{kg}$ doses of the aqueous extract as post-treatment caused a decrease in SOD activity by $38 \%$ to $81 \%$ of

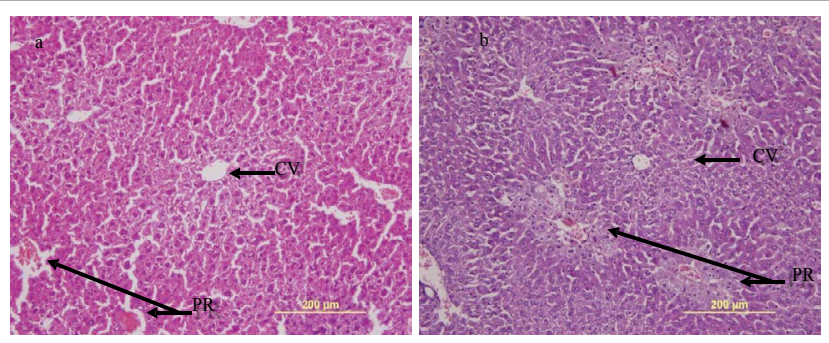

Figure 1: Photomicrographs of Haematoxylin \& Eosin stained sections at magnification $20 \mathrm{X}$ of mouse liver fed with: a: normal saline treatment $($ Grade $=0.0)$ arrows indicates normal arrangement of hepatocytes around the central vein (CV) and portal region (PR) and b: $550 \mathrm{mg} / \mathrm{kg}$ acetaminophen treatment (Grade 3.0) with derangement of hepatocytes around the around the portal regions (PR) extending for more than 3 cell layers to central vein (CV).
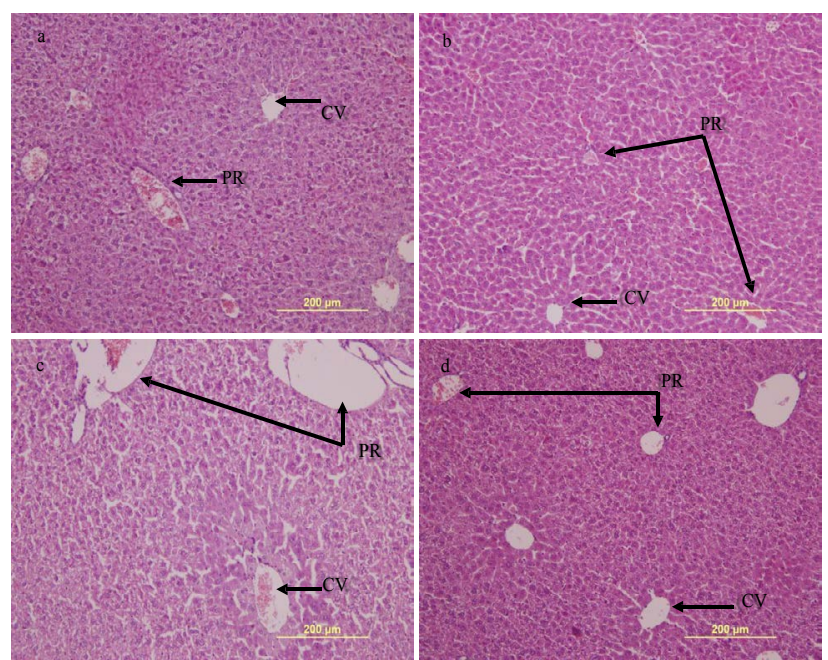

Figure 2: Photomicrographs of Haematoxylin \& Eosin stained sections a magnification 20X of mouse liver fed a pre-treatment of $L$. nepetifolia methanol leaf extract at a dose of: a: $250 \mathrm{mg} / \mathrm{kg}$ (Grade 0.0); b: $500 \mathrm{mg} / \mathrm{kg}$ (Grade 0.0); c: $750 \mathrm{mg} / \mathrm{kg}$ (Grade 0.75 ) and d: $1000 \mathrm{mg} / \mathrm{kg}$ (Grade 0.0), arrows indicated the location of the central vein $\mathrm{CV}$ and portal region $\mathrm{PR}$. 
Citation: Williams AF, Clement YN, Nayak SB, Rao AVC (2016) Leonotis nepetifolia Protects against Acetaminophen-Induced Hepatotoxicity: Histological Studies and the Role of Antioxidant Enzymes. Nat Prod Chem Res 4: 222. doi:10.4172/2329-6836.1000222

Page 4 of 7

\begin{tabular}{|c|c|c|c|c|c|}
\hline Treatment & $\begin{array}{c}\text { Dose } \\
\text { (mg/kg) }\end{array}$ & \multicolumn{2}{|c|}{ ALT (IU/L) } & \multicolumn{2}{|c|}{ AST (IU/L) } \\
\hline Control & Saline & \multicolumn{2}{|c|}{$69.67 \pm 4.47$} & \multicolumn{2}{|c|}{$301.50 \pm 30.61$} \\
\hline \multirow[t]{2}{*}{ Acetaminophen } & 550 & \multicolumn{2}{|c|}{$976.33 \pm 128.24$} & \multicolumn{2}{|c|}{$1307.83 \pm 225.47$} \\
\hline & & Methanol extract & Aqueous extract & Methanol extract & Aqueous extract \\
\hline \multirow{4}{*}{ Pre-treatment } & 250 & $65.90 \pm 18.26^{*}$ & $58.75 \pm 5.66^{*}$ & $213.40 \pm 37.69^{*}$ & $275.50 \pm 29.37^{*}$ \\
\hline & 500 & $59.90 \pm 10.41^{*}$ & $47.00 \pm 4.81^{*}$ & $240.10 \pm 28.82^{*}$ & $284.00 \pm 92.03^{*}$ \\
\hline & 750 & $218.25 \pm 87.77^{*} !$ & $51.00 \pm 19.80^{*}$ & $382.58 \pm 130.42^{*}$ & $150.50 \pm 50.07^{*}$ \\
\hline & 1000 & $204.75 \pm 99.41^{*} !$ & $307.50 \pm 126.95^{*} !$ & $501.17 \pm 162.13^{*} !$ & $265.67 \pm 121.07^{*}$ \\
\hline \multirow{4}{*}{ Post-treatment } & 250 & $82.40 \pm 16.73^{*}$ & $65.90 \pm 18.25^{*}$ & $183.00 \pm 19.36^{\star}$ & $213.40 \pm 37.68^{*}$ \\
\hline & 500 & $148.83 \pm 19.03^{*}$ & $59.90 \pm 10.41^{*}$ & $334.83 \pm 17.68^{*}$ & $240.10 \pm 28.82^{*}$ \\
\hline & 750 & $79.38 \pm 7.18^{*}$ & $218.25 \pm 87.76^{*}$ & $288.63 \pm 9.32^{*}$ & $382.58 \pm 130.42^{*}$ \\
\hline & 1000 & $71.33 \pm 9.16$ * & $204.75 \pm 99.41^{*}$ & $227.67 \pm 43.35^{*}$ & $501.16 \pm 162.13^{*} !$ \\
\hline
\end{tabular}

Table 1: ALT/AST. Serum ALT and AST concentrations (U/L) in mice pre-and post-treated with $L$. nepetifolia methanol or aqueous leaf extracts against acetaminopheninduced toxicity $\left(p<0.05\right.$, APAP-treated alone compared to normal saline control; ${ }^{*} p<0.05$, APAP-treated alone compared to extract treated and ! $<<0.05$, normal saline control compared to extract treated).

\begin{tabular}{|c|c|c|c|}
\hline \multirow{2}{*}{ Treatment } & $\begin{array}{c}\text { Dose } \\
\text { (mg/kg) }\end{array}$ & \multicolumn{2}{|c|}{ Histological grade } \\
\hline Control & Saline & \multicolumn{2}{|c|}{$0.00 \pm 0.00$} \\
\hline \multirow{2}{*}{ Acetaminophen } & 550 & \multicolumn{2}{|c|}{$2.50 \pm 0.23$} \\
\hline \multirow{2}{*}{ Pre-treatment } & & Methanol extract & Aqueous extract \\
\hline \multirow{2}{*}{} & 250 & $0.33 \pm 0.33^{*}$ & $0.00 \pm 0.00^{*}$ \\
\cline { 2 - 4 } & 500 & $0.46 \pm 0.33^{*}$ & $0.00 \pm 0.00^{*}$ \\
\hline \multirow{2}{*}{ Post-treatment } & 1000 & $0.80 \pm 0.80^{*}$ & $0.86 \pm 0.72^{*}$ \\
\cline { 2 - 4 } & 250 & $1.30 \pm 0.73$ & $1.08 \pm 0.60^{*}$ \\
\hline & 500 & $0.50 \pm 0.50^{*}$ & $2.50 \pm 0.92 !$ \\
\cline { 2 - 4 } & 750 & $0.50 \pm 0.16^{*}$ & $0.40 \pm 0.24^{*}$ \\
\hline & 1000 & $0.00 \pm 0.00^{*}$ & $2.08 \pm 0.37 !$ \\
\hline
\end{tabular}

Table 2: Histological Grade. Histological Grading in mice pre- and post- treated with $L$. nepetifolia methanol or aqueous leaf extracts against acetaminopheninduced toxicity $(\bullet p<0.05$, APAP-treated alone compared to normal saline control; ${ }^{*} \mathrm{p}<0.05$, APAP-treated alone compared to extract treated and ! $<0.05$, norma saline control compared to extract treated).
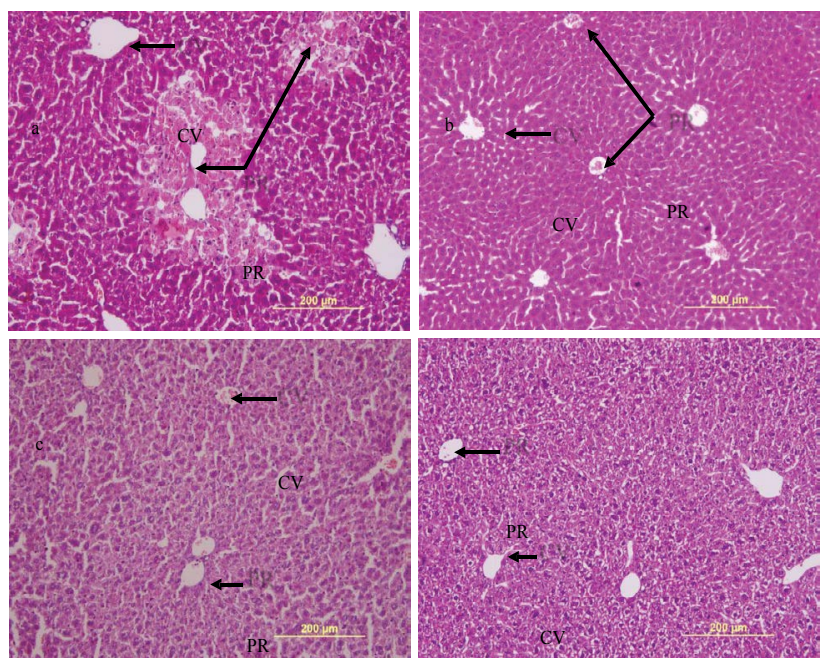

Figure 3: Photomicrographs of Haematoxylin \& Eosin stained sections at magnification $20 \mathrm{X}$ of mouse liver fed a post-treatment of $L$. nepetifolia methanol leaf extract at a dose of: a: $250 \mathrm{mg} / \mathrm{kg}$ (Grade 3.0); b: $500 \mathrm{mg} / \mathrm{kg}$ (Grade 0.0); c: $750 \mathrm{mg} / \mathrm{kg}$ (Grade 0.0) and d: $1000 \mathrm{mg} / \mathrm{kg}$ (Grade 0.0 ), arrows indicated the location of the central vein $\mathrm{CV}$ and portal region PR.

saline-treated animals (Table 4) and abolished the significant APAPinduced increase in enzyme activity $(\mathrm{F}(6,33)=318.50, p<0.05)$.

Pre-treatment with methanol extract increased GPx activity between $6 \%$ and $59 \%$ compared with saline-treated controls (Table 3). However, all doses significantly reversed the APAP-induced decrease in GPx activity $(F(6,28)=12.19, p<0.01)$. Similarly, all doses of the aqueous extract as pre-treatment caused an increase (between 1.4-fold to 2.2-fold) in GPx activity compared to the saline-treated controls and reversed the APAP-induced decline in enzyme activity $(\mathrm{F}(6,28)=12.19$ $(\mathrm{p}<0.01)$ with an effect size $(\eta 2)$ of $72.3 \%$.

Post-treatment with methanol extract increased GPx activity between $8 \%$ and $50 \%$ compared with saline-treated controls (Table 3). However, all doses significantly abrogated the APAP-induced decline in enzyme activity $(F(6,35)=9.14, p<0.05)$ with an effect size $(\eta 2)$ of $61.7 \%$. Similarly, the aqueous extract as post-treatment increased GPx activity between $30 \%$ and $82 \%$ over saline- treated controls (Table 4 ), and significantly abolished the APAP-induced decrease in enzyme activity $(F(6,32)=15.37, p<0.01)$ with an effect size $(\eta 2)$ of $73.3 \%$.

Pre-treatment with methanol extract arrogated the 4-fold APAPinduced elevation in GR activity $(\mathrm{F}(6,33)=22.99, p<0.05)$, although enzyme activity across the dose range increased by up to $38 \%$ over the saline-treated controls. Similarly, pre-treatment with all doses of aqueous extracts abolished the significant APAP-induced increase in GR activity $\mathrm{F}(6,28)=19.79$ ( $\mathrm{p}<0.01)$ with an effect size $(\eta 2)$ of $80.9 \%$, although there was an increase in enzyme activity between $35 \%$ and $72 \%$ over saline-treated controls.

All doses of the methanol extract as post-treatment abolished the significant APAP-induced increase in GR activity. Despite the moderate elevation of GR activity between $52 \%$ and $78 \%$ over the dose range over the saline-treated controls, this was significantly lower than the 4-fold increase seen with APAP alone $(\mathrm{F}(6,35)=20.25, p<0.05)$. Similarly, all doses of the aqueous extract as post-treatment abrogated the significant 4 -fold increase in enzyme activity by $\operatorname{APAP}(\mathrm{F}(6,28)=19.79, p<0.01)$. However, all doses also caused significant increases in enzyme activity between $72 \%$ and $126 \%$ over saline-treated controls $(\mathrm{F}(6,32)=14.66$, $p<0.01)$.

Although high-dose APAP caused a slight decrease in CAT activity, this was statistically insignificant $(p>0.05)$. For the methanol extract, except for the post-treatment dose of $250 \mathrm{mg} / \mathrm{kg}$ where there was a non-significant decrease, all pre-treatment and post-treatment 
Citation: Williams AF, Clement YN, Nayak SB, Rao AVC (2016) Leonotis nepetifolia Protects against Acetaminophen-Induced Hepatotoxicity: Histological Studies and the Role of Antioxidant Enzymes. Nat Prod Chem Res 4: 222. doi:10.4172/2329-6836.1000222

Page 5 of 7

\begin{tabular}{|c|c|c|c|c|c|}
\hline Treatment & $\begin{array}{c}\text { Dose } \\
(\mathrm{mg} / \mathrm{kg})\end{array}$ & $\begin{array}{c}\text { CAT } \\
\text { (nmol/min/ml) }\end{array}$ & SOD (U/mL) & $\begin{array}{c}\text { GPx } \\
\text { (nmol/min/ml) }\end{array}$ & $\begin{array}{c}\text { GR } \\
(\mathrm{nmol} / \mathrm{min} / \mathrm{ml})\end{array}$ \\
\hline Control & Saline & $1979.84 \pm 111.71$ & $19.78 \pm 1.23$ & $49.66 \pm 5.47$ & $45.51 \pm 4.87$ \\
\hline Acetaminophen & 550 & $1817.80 \pm 63.65$ & $282.45 \pm 14.26$ & $17.09 \pm 3.53$ & $180.69 \pm 17.08$ \\
\hline \multirow[t]{4}{*}{ Pre-treatment } & 250 & $1909.17 \pm 70.05$ & $20.94 \pm 2.09^{*}$ & $72.58 \pm 11.67^{*}$ & $52.97 \pm 4.69^{*}$ \\
\hline & 500 & $2059.92 \pm 102.49$ & $29.98 \pm 6.13^{*}$ & $78.95 \pm 7.69^{*}$ & $61.12 \pm 7.80^{*}$ \\
\hline & 750 & $1984.45 \pm 54.77$ & $48.10 \pm 10.41^{*}$ & $75.13 \pm 5.48^{*}$ & $46.55 \pm 5.44^{*}$ \\
\hline & 1000 & $1982.53 \pm 132.17$ & $78.17 \pm 4.82^{*} !$ & $52.76 \pm 8.97^{*}$ & $62.83 \pm 9.16^{*}$ \\
\hline \multirow[t]{4}{*}{ Post-treatment } & 250 & $1734.87 \pm 194.32$ & $5.01 \pm 1.25^{*}$ & $53.49 \pm 5.55^{\star}$ & $80.79 \pm 11.40^{*}$ \\
\hline & 500 & $2151.37 \pm 97.29$ & $6.94 \pm 0.45^{*}$ & $73.22 \pm 6.31^{*}$ & $69.33 \pm 6.27^{*}$ \\
\hline & 750 & $2079.30 \pm 99.74$ & $55.87 \pm 3.33^{*}$ & $64.50 \pm 5.83^{*}$ & $68.98 \pm 6.04^{*}$ \\
\hline & 1000 & $1951.33 \pm 110.04$ & $11.33 \pm 1.39^{*}$ & $74.29 \pm 8.80^{*}$ & $80.23 \pm 6.28^{*}$ \\
\hline
\end{tabular}

Table 3: Antioxidant enzymes (Methanol extract). Antioxidant enzymes in mice pre- and post- treated with $L$. nepetifolia leaf extract against acetaminophen-induced toxicity $\left(p<0.05\right.$, APAP-treated alone compared to normal saline control; ${ }^{*} p<0.05$, APAP-treated alone compared to extract treated and ! $p<0.05$, normal saline control compared to extract treated).

\begin{tabular}{|c|c|c|c|c|c|}
\hline Treatment & $\begin{array}{l}\text { Dose } \\
(\mathbf{m g} / \mathbf{k g})\end{array}$ & $\begin{array}{c}\text { CAT } \\
\text { (nmol/min/ml) }\end{array}$ & SOD (U/mL) & $\begin{array}{c}\text { GPx } \\
\text { (nmol/min/ml) }\end{array}$ & $\begin{array}{c}\text { GR } \\
\text { (nmol/min/ml) }\end{array}$ \\
\hline Control & Saline & $1979.84 \pm 111.71$ & $19.78 \pm 1.23$ & $49.66 \pm 5.47$ & $45.51 \pm 4.87$ \\
\hline Acetaminophen & 550 & $1817.80 \pm 63.65$ & $282.45 \pm 14.26$ & $17.09 \pm 3.53$ & $180.69 \pm 17.08$ \\
\hline \multirow[t]{4}{*}{ Pre-treatment } & 250 & $1725.25 \pm 212.47$ & $16.56 \pm 4.63^{*}$ & $108.84 \pm 20.70$ * & $61.34 \pm 4.75^{*}$ \\
\hline & 500 & $1849.52 \pm 107.52$ & $45.50 \pm 2.97^{*}$ & $108.24 \pm 15.60^{*}$ & $76.41 \pm 6.74^{*}$ \\
\hline & 750 & $1788.84 \pm 131.53$ & $22.51 \pm 3.52^{*}$ & $70.04 \pm 11.33^{*}$ & $78.32 \pm 7.52^{*}$ \\
\hline & 1000 & $1980.18 \pm 112.13$ & $20.28 \pm 2.07^{*}$ & $47.75 \pm 3.58^{*}$ & $77.68 \pm 7.29^{*}$ \\
\hline \multirow[t]{4}{*}{ Post-treatment } & 250 & $1976.76 \pm 151.32$ & $22.47 \pm 1.52^{*}$ & $47.66 \pm 3.93^{*}$ & $94.10 \pm 12.07^{*}$ \\
\hline & 500 & $1750.03 \pm 164.38$ & $16.14 \pm 0.97^{*}$ & $66.22 \pm 4.32^{*}$ & $97.80 \pm 10.38^{*}$ \\
\hline & 750 & $1821.51 \pm 49.89$ & $10.41 \pm 0.92^{*}$ & $90.42 \pm 4.68^{*}$ & $78.44 \pm 12.10^{*}$ \\
\hline & 1000 & $1824.85 \pm 174.19$ & $7.64 \pm 1.28^{*} !$ & $64.73 \pm 7.96^{*}$ & $102.87 \pm 7.52^{*}$ \\
\hline
\end{tabular}

Table 4: Antioxidant enzymes (Aqueous extract). Antioxidant enzymes in mice pre- and post-treated with $L$. nepetifolia leaf extracts against acetaminophen-induced toxicity $\left(\diamond p<0.05\right.$, APAP-treated alone compared to normal saline control; ${ }^{*} p<0.05$, APAP-treated alone compared to extract treated and ! $p<0.05$, normal saline control compared to extract treated)
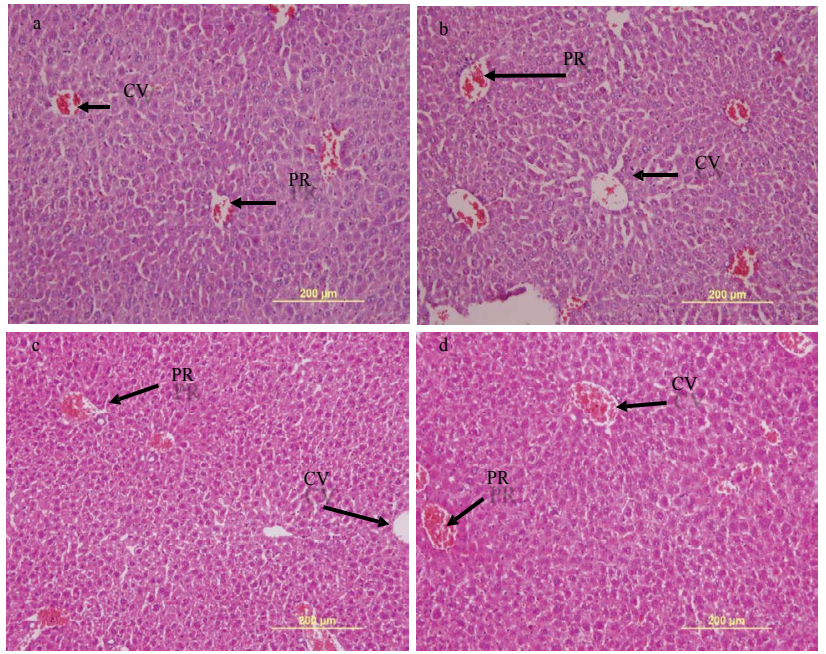

Figure 4: Photomicrographs of Haematoxylin \& Eosin stained sections at magnification 20X of mouse liver fed a pre-treatment of $L$. nepetifolia aqueous leaf extract at a dose of: a: $250 \mathrm{mg} / \mathrm{kg}$ (Grade 0.0); b: $500 \mathrm{mg} / \mathrm{kg}$ (Grade 3.0); c: $750 \mathrm{mg} / \mathrm{kg}$ (Grade 0.0 ) and $\mathrm{d}: 1000 \mathrm{mg} / \mathrm{kg}$ (Grade 0.0 ), arrows indicated the location of the central vein $\mathrm{CV}$ and portal region PR.

doses produced a non-significant increase in hepatic catalase activity over APAP alone (Tables 3 and 4). However, only the post-treatment methanol extract at $500 \mathrm{mg} / \mathrm{kg}$ produced a significant increase in enzyme activity $(p=0.02)$. For the aqueous extract, none of the treatments produced significant changes in enzyme activity compared to APAP-alone treatment.
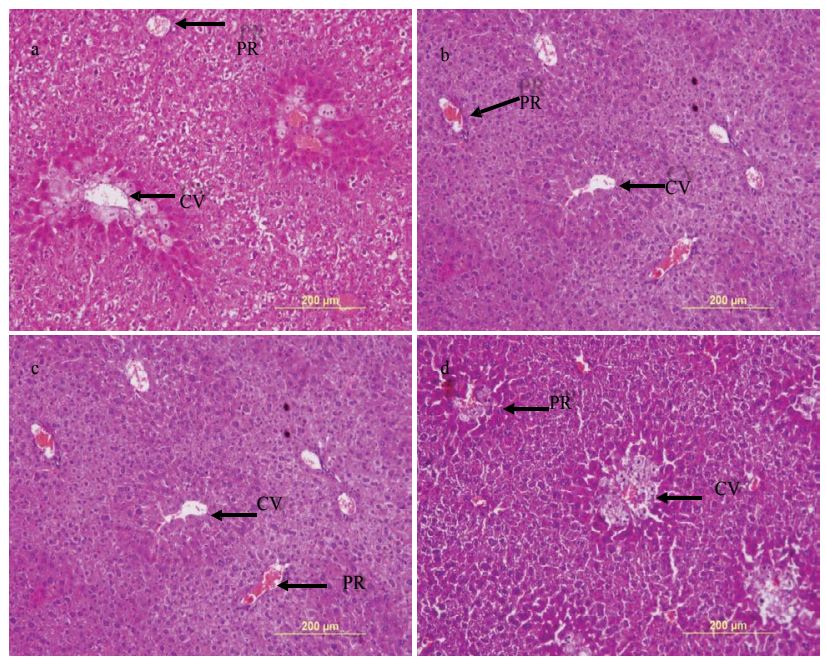

Figure 5: Photomicrographs of Haematoxylin \& Eosin stained sections a magnification $20 X$ of mouse liver fed a post-treatment of $L$. nepetifolia aqueous leaf extract at a dose of: a: $250 \mathrm{mg} / \mathrm{kg}$ (Grade 2.0); b: $500 \mathrm{mg} / \mathrm{kg}$ (Grade 0.0); c: $750 \mathrm{mg} / \mathrm{kg}$ (Grade 0.0) and d: $1000 \mathrm{mg} / \mathrm{kg}$ (Grade 2.0), arrows indicated the location of the central vein $\mathrm{CV}$ and portal region PR.

\section{Discussion}

The results of our study showed that both pre-treatment and posttreatment with aqueous and methanol extracts of Leonotis nepetifolia prevented the APAP-induced hepatotoxicity in Swiss albino mice. This was demonstrated by the extracts' ability to abolish the dramatic APAP-induced rise in liver enzymes (ALT and AST) and maintained 
Citation: Williams AF, Clement YN, Nayak SB, Rao AVC (2016) Leonotis nepetifolia Protects against Acetaminophen-Induced Hepatotoxicity: Histological Studies and the Role of Antioxidant Enzymes. Nat Prod Chem Res 4: 222. doi:10.4172/2329-6836.1000222

normal hepatic morphology. A recent study by Ref. [20] showed that the aqueous extract $L$. nepetifolia, given as chronic post- treatment, protected against $\mathrm{CCl}_{4}$-induced hepatic damage in rats in a similar manner. Additionally, several studies have shown that the methanol and aqueous extracts of some medicinal plants protect against APAPinduced hepatotoxicity by abrogating the drug-induced increase in liver enzymes and maintaining normal liver morphology [21-24]. Several studies have identified antioxidant phytochemicals, such as polyphenols and flavonoids, which were suggested to be responsible for the medicinal plants' protective properties against APAP-induced hepatic injury [25-28].

Few studies have attempted to determine the direct effect of these hepatoprotective herbal extracts on of antioxidant enzyme activity. We hypothesized that known antioxidant compounds present in $L$. nepetifolia may be modulating the activity of antioxidant enzymes and therefore play an important role in protecting the liver against APAP-induced injury. The study by Ref. [20] also investigated the post-treatment effects of aqueous L. nepetifolia extract on the activities of GPx, CAT and SOD in the $\mathrm{CCl}_{4}$-induced model of hepatic injury. These researchers showed that the plant extract had a dose-dependent effect to reverse the $\mathrm{CCl}_{4}$-induced suppression in the activities of these antioxidant enzymes.

Glutathione plays a critical role in maintaining cellular redox balance, and high doses of APAP cause significant depletion this endogenous tripeptide antioxidant with accumulation of reactive oxygen species (ROS) leading to cellular injury and necrosis, with subsequent protein binding and lipid peroxidation [5]. To maintain this redox balance, glutathione is cycled between its reduced (GSH) and oxidized (GSSG) forms under the influence of GR and GPx. From our results, the ratio between GPx and GR in hepatic tissue of untreated control animals was approximately $1: 1$.

High-dose APAP caused a significant shift in the ratio in activities of these antioxidant enzymes from 1:1 to 1:10; with GPx activity falling to about $35 \%$ of saline-treated controls, with a dramatic 4 -fold rise in GR activity. The cellular levels of the reduced form are critical, as it readily binds ROS to reduce oxidative stress. This is supported by our results where increased GR activity suggests a cellular response to generate more reduced glutathione that would scavenge increasing concentrations of NAPQI produced by the metabolism of high dose APAP.

The APAP-induced attenuation in GPx activity would cause an accumulation of hydroperoxides and peroxide radicals that subsequently leads to an increase in SOD activity to remove these reactive species. However, the compensatory increase in SOD activity would not have been sufficient to prevent damage caused by these reactive species. We also observed an insignificant decline in CAT activity in the presence of high dose APAP. In their study which investigated the hepatoprotective effects of Baccharis trimera in rats, [29] showed that APAP at $835 \mathrm{mg} / \mathrm{kg}$ increased SOD activity, whilst suppressing the activities of both GR and GPx.

In our study, pre-treatment and post-treatment with both methanol and aqueous extracts reversed the APAP-induced suppression of GPx activity; and notably the pre-treatment aqueous extract produced between 1.4 fold to 2.2 fold increase in activity compared with saline-treated controls. These results hold the key to understanding a possible mechanism by which $L$. nepetifolia extracts may be providing hepatoprotection against APAP insult (Figure 6). Increasing GPx activity would increase the liver's capacity to remove toxic celldamaging hydroperoxides and peroxide radicals, thus preventing injury [30]. It may be possible that this increased activity is due to transcriptional up-regulation of the gene and/or post-translational modification of the protein (enzyme) in the pre-treatment model. But, it is noteworthy that this effect is also observed in the post-treatment model even after the liver was exposed to damaging reactive species before the administration of L. nepetifolia extracts; this points to posttranslational modification of already formed enzyme.

Although the study by Ref. [20] showed that L. nepetifolia reversed the $\mathrm{CCl}_{4}$-induced decline in GPx, enzyme activity just returned to control levels at the highest dose of $300 \mathrm{mg} / \mathrm{kg}$. In another study, an extract of $B$. trimera extract did not reverse the APAP-induced diminution of GPx activity [29].

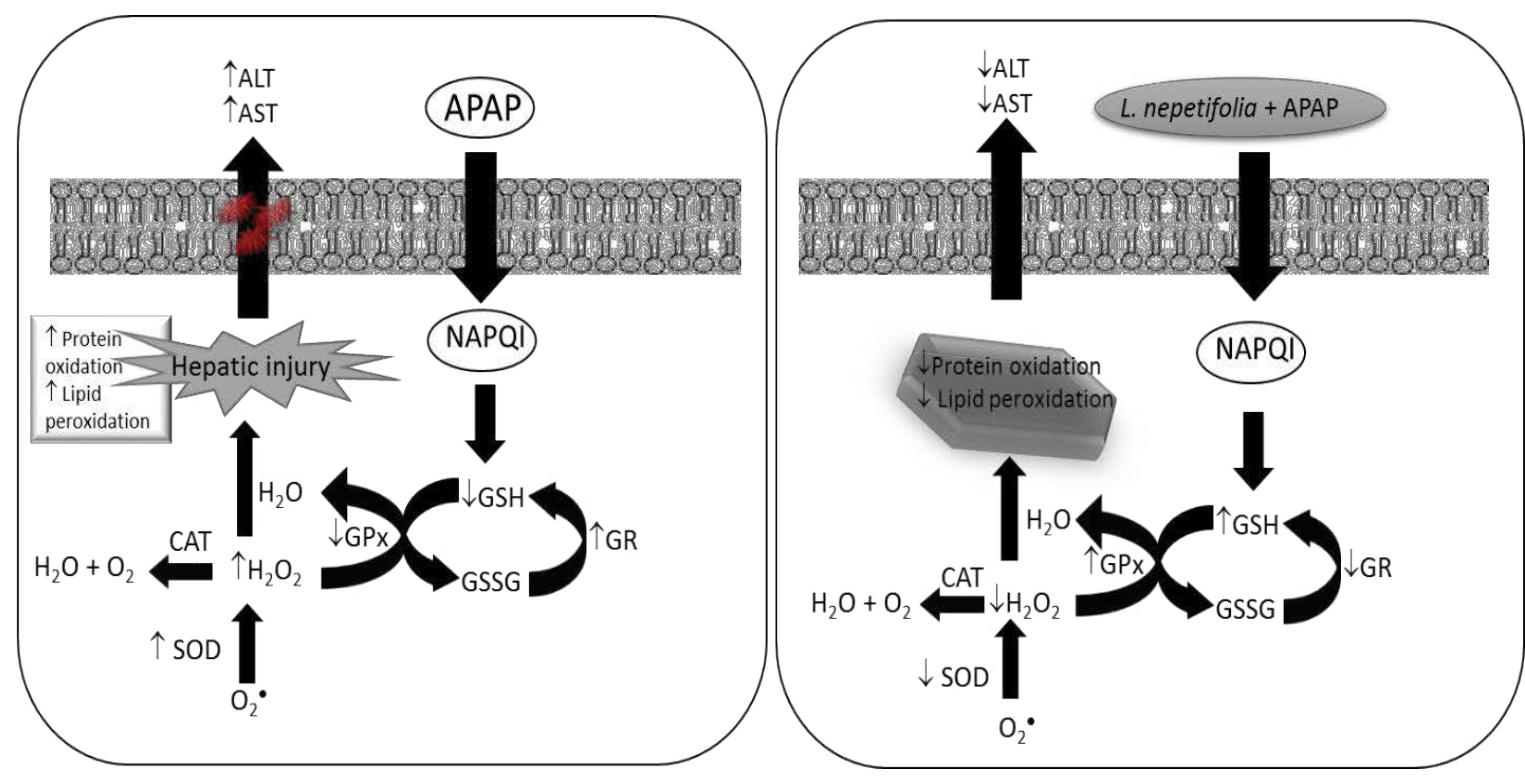

Figure 6: Illustration showing the protective effect of $L$. nepetifolia in acetaminophen- induced liver toxicity. Adapted from Padua Bda et al. in comparison to NS controls, APAP toxicity causes oxidative stress with decreased GSH levels, GPx enzyme activity and increased SOD activity resulting in elevation of $\mathrm{H}_{2} \mathrm{O}_{2}$ specifically by elevated serum ALT and AST. Administration of $L$. nepetifolia maintains oxidative balance during APAP treatment. By increasing GSH levels, GPx activity and reducing SOD activity with maintained oxidative balance and lowered serum ALT and AST cellular integrity was maintained. 
Citation: Williams AF, Clement YN, Nayak SB, Rao AVC (2016) Leonotis nepetifolia Protects against Acetaminophen-Induced Hepatotoxicity: Histological Studies and the Role of Antioxidant Enzymes. Nat Prod Chem Res 4: 222. doi:10.4172/2329-6836.1000222

All doses of both extracts as pre-treatment and post-treatment caused a moderate increase in GR activity (up to 2-fold increase in aqueous post-treatment); however, they prevented the significant 4-fold increase seen with APAP alone. Although we did not measure hepatic glutathione levels, these results suggest that there was a reduced requirement to generate this endogenous antioxidant as other mechanisms would have been at play to scavenge reactive species, such as increased GPx activity. Despite the perturbations in absolute GPx and GR activities, it should be noted that the ratio of these enzymes were close to $1: 1$ as seen in saline-treated controls. It may be possible that antioxidant compounds in L. nepetifolia may be triggering a cellular response to maintain the redox cycling of glutathione; as opposed to the 1:10 ratio seen in the livers of animals treated with APAP alone.

Pre- and post-treatment with both extracts abrogated the APAPinduced elevation of SOD activity. Although the enzymes levels for these treatments ranged between $25 \%$ decrease to 4 -fold increase over saline controls, which was significantly lower than the 14 -fold increase seen with high dose APAP. These results suggest that there is a reduced requirement to scavenge hydroperoxides and peroxide radicals in the presence of the extracts, which may be due to increased GPx activity or direct antioxidant effects of phytochemicals. In a study conducted by Ref. [31] which looked at the extract's anti-inflammatory effects and found that some possible active isolates included stigmasterols, diterpenes, labdanes and leonotinin which may also be providing the antioxidant capability.

\section{Conclusions}

Leonotis nepetifolia possesses a significant potential for hepatoprotection against APAP-induced toxicity possibly directly through phytochemicals contained in the extract. The extract components may be providing an up-regulation of genes during transcription of proteins (enzymes) to reduce the demand for increased GR activity during APAP toxicity. This also suggests the possible modification to augment activity of endogenous antioxidant enzymes for more efficient removal of pro-oxidants during toxic insult. Our findings therefore suggest that aqueous and methanol extracts of $L$. nepetifolia may be useful in the treatment of acetaminophen overdose.

\section{References}

1. Blieden M, Paramore LC, Shah D, Ben-Joseph R (2014) A perspective on the epidemiology of acetaminophen exposure and toxicity in the United States. Expert Rev Clin Pharmacol 7: 341-348.

2. Doyon S, Klein-Schwartz W, Lee S, Beuhler MC (2013) Fatalities involving acetaminophen combination products reported to United States poison centers. Clin Toxicol 51: 941-948.

3. Manthripragada AD, Zhou EH, Budnitz DS, Lovegrove MC, Willy ME (2011) Characterization of acetaminophen overdose-related emergency department visits and hospitalizations in the United States. Pharmacoepidemiol Drug Saf 20: 819-826.

4. Myers RP, Li B, Shaheen AA (2007) Emergency department visits for acetaminophen overdose: a Canadian population-based epidemiologic study (1997-2002). CJEM 9: 267-274.

5. Bessems JGM, Vermeulen NPE (2001) Paracetamol (Acetaminophen)-Induced Toxicity: Molecular and Biochemical Mechanisms, Analogues and Protective Approaches. Crit. Rev. Toxicol. 31: 55-138.

6. Al-Asmari AK, Al-Elaiwi AM, Athar MT, Tariq M, Al Eid A, et al. (2014) A review of hepatoprotective plants used in saudi traditional medicine. Evid Based Complement Alternat Med 2014: 890842.

7. Girish C, Pradhan SC (2012) Indian herbal medicines in the treatment of liver diseases: problems and promises. Fundam Clin Pharmacol 26: 180-189.

8. Madrigal-Santillan E, Madrigal-Bujaidar E, Alvarez-Gonzalez I, SumayaMartinez MT, Gutierrez-Salinas J, et al. (2014) Review of natural products with hepatoprotective effects. World J Gastroenterol 20: 14787-14804.

9. Clement YN, Baksh-Comeau YS, Seaforth CE (2015) An ethnobotanical survey of medicinal plants in Trinidad. J Ethnobiol Ethnomed 11: 67.
10. Carrington S (1998) Wild Plants of the Eastern Caribbean. Macmillan Education Ltd., London and Basingstoke.

11. Govindasamy L, Rajakannan V, Velmurugan D, Banumathi S, Vasanath $S$ (2002) Structural Studies on Three Plant Diterpenoids from Leonotis nepetaefolia. Cryst Res Technol 37: 896-909.

12. Rojas LB, Cordero De Rojas Y, Carmona AJ (2007) Volatile components of the leaves of Leonotis nepetifolia (L.) R. Br. that grows in the Mérida State, Venezuela. Ciencia 15: 357-360.

13. Sobolewska Pasko P, Galanty A, Makowska-Was J, Padlo K, Wasilak W (2012) Preliminary phytochemical and biological screening of methanolic and acetone extracts from Leonotis nepetifolia (L.) R Br. J Med Plants Res 6: 4582-4585.

14. Takeda T, Narukawa Y, Hada N (1999) Studies on the constituents of Leonotis nepetaefolia. Chem Pharm Bull 47: 284-286.

15. Hoff J (2000) Methods of Blood Collection in the Mouse. Technique 29: 47-53.

16. Sadasivan S, Latha PG, Sasikumar JM, Rajashekaran S, Shyamal S, et al. (2006) Hepatoprotective studies on Hedyotis corymbosa (L.) Lam. J Ethnopharmacol 106: 245-249.

17. Culling CFA (1963) Histopathological Techniques Including Meusum Techniques. 2nd edn. Buttersworths and Company Limited, London.

18. Gunawan BK, Liu ZX, Han D, Hanawa N, Gaarde WA, et al. (2006) c-Jun Nterminal kinase plays a major role in murine acetaminophen hepatotoxicity. Gastroenterology 131: 165-178.

19. Wheeler CR, Salzman JA, Elsayed NM, Omaye ST, Korte Jr DW (1990) Automated assays for superoxide dismutase, catalase, glutathione peroxidase, and glutathione reductase activity. Anal Biochem 184: 193-199.

20. Radhika J, Pradeep V, Brindha P (2011) Protective effect of aqueous extract of Leonotis nepaetifolia (L.) R.Br. on CCL4 induced hepatic damage. J Pharm Res 4: 630-631.

21. Eesha BR, Mohanbabu Amberkar V, Meena Kumari K, Sarath B, Vijay M, et al. (2011) Hepatoprotective activity of Terminalia paniculata against paracetamo induced hepatocellular damage in Wistar albino rats. Asian Pac J Trop Med 4 466-469.

22. Kamisan FH, Yahya F, Ismail NA, Din SS, Mama SS, et al. (2013) Hepatoprotective activity of methanol extract of Melastoma malabathricum leaf in rats. J Acupunct Meridian Stud 6: 52-55.

23. Kiran PM, Raju AV, Rao BG (2012) Investigation of hepatoprotective activity of Cyathea gigantea (Wall. ex. Hook.) leaves against paracetamol-induced hepatotoxicity in rats. Asian Pac J Trop Biomed 2: 352-356.

24. Nithianantham K, Shyamala M, Chen Y, Latha LY, Jothy SL, et al. (2011) Hepatoprotective potential of Clitoria ternatea leaf extract against paracetamo induced damage in mice. Molecules 16: 10134-10145.

25. Adeneye AA (2009) Protective activity of the stem bark aqueous extract of Musanga cecropioides in carbon tetrachloride- and acetaminophen-induced acute hepatotoxicity in rats. Afr J Tradit Complement Altern Med 6: 131-138.

26. Aseervatham GS, Sivasudha T, Sasikumar JM, Christabel PH, Jeyadevi R, et al. (2014) Antioxidant and hepatoprotective potential of Pouteria campechiana on acetaminophen-induced hepatic toxicity in rats. J Physiol Biochem 70: 1-14

27. Biswas K, Kumar A, Babaria BA, Prabhu K, Setty RS (2009) Hepatoprotective effect of leaves of Peltophorum pterocarpum against paracetamol Induced acute liver damage in rats. J Basic Clin Pharm 1: 10-15.

28. Ghanem MT, Radwan HM, Mahdy el SM, Elkholy YM, Hassanein HD, et al (2012) Phenolic compounds from Foeniculum vulgare (Subsp. Piperitum) (Apiaceae) herb and evaluation of hepatoprotective antioxidant activity. Pharmacogn. Res 4: 104-108.

29. Padua Bda C, Rossoni Junior JV, Magalhaes CL, Chaves MM, Silva ME, et al. (2014) Protective effect of Baccharis trimera extract on acute hepatic injury in a model of inflammation induced by acetaminophen. Mediat Inflamm 2014: 196598.

30. Lubos E, Kelly NJ, Oldebeken SR, Leopold JA, Zhang YY, et al. (2011) Glutathione peroxidase-1 deficiency augments proinflammatory cytokineinduced redox signaling and human endothelial cell activation. J Biol Chem 286: 35407-35417.

31. Parra-Delgado H, Ruiz GG, Camacho AN, Martínez-Vazquez (2004) Antiinflammatory activity of some extracts and isolates from Leonotis nepetifolia on TPA-induced edema model. Investigación Rev Soc Quím Méx 48: 293-295. 